\title{
Status and conservation of Imperial and Red-necked Parrots Amazona imperalis and A. arausiaca on Dominica
}

\author{
PETER G. H. EVANS
}

\section{Summary}

Populations of both Imperial and Red-necked Parrots on Dominica have declined during the present century with substantial contractions in range, particularly from the southern portion of the island. Parrot densities may be relatively low anyway due to the effects of centuries of hunting. However, declines have been accelerated by habitat destruction and loss of food plants and nesting sites as a result of both human encroachment on the forest and damage caused by Hurricanes David and Allen in 1979 and 1980 respectively. The hunting of birds for meat and for the live cage-bird trade were important threats in the past but conservation education programmes over the last 10 years, and enforcement of legislation prohibiting those activities, have greatly reduced these pressures. Ten years after the debilitating effects of the two hurricanes, the populations of both parrot species (but particularly Red-necks) are showing signs of recovery. Present estimates (May 1990) are of $c .80$ Imperial Parrots and c.300 Red-necked Parrots in the wild. The major threat to both parrot species is presently habitat destruction, with forested areas being cleared at an accelerating rate for the planting of tree crops, particularly bananas. This process has been aided by recent development programmes towards the building and improvement of feeder roads, making previously remote areas much more accessible. The need for the north-west portion of the Northern Forest Reserve (which includes the entire Morne Diablotin massif) to be declared a national park is ever more critical if the two parrot species are to survive in the long term.

\section{Introduction}

Six parrots of the genus Amazona inhabit the eastern Caribbean with four species in the Lesser Antilles, each occupying a single island (Figure 1). Two of these these live on the mountainous island of Dominica. The Imperial Parrot Amazona imperialis, or Sisserou as it is known locally, is the largest member of the genus. Magnificently plumaged with a deep green back, purple head, neck and underparts, the Imperial is the most distinctive of all the amazons. It is also one of the rarest, its population reduced, particularly by habitat loss or damage over the last decade, to the verge of extinction. The Red-necked Parrot Amazona arausiaca, known locally as Jaco, is a more typical Amazon - smaller, mainly bright green but with a bluish head, distinctive red areas on the neck and upper breast and a scarlet wing patch. In flight it is best distinguished by its yellowish-green tail, its shallower wing beat, and, particularly, by its higher-pitched harsh cry or squawk. The cry of the Imperial is more modulated, somewhat resembling a trumpet. Red-necked Parrots are commoner than Imperials but nevertheless have also suffered from changes to their habitat. 


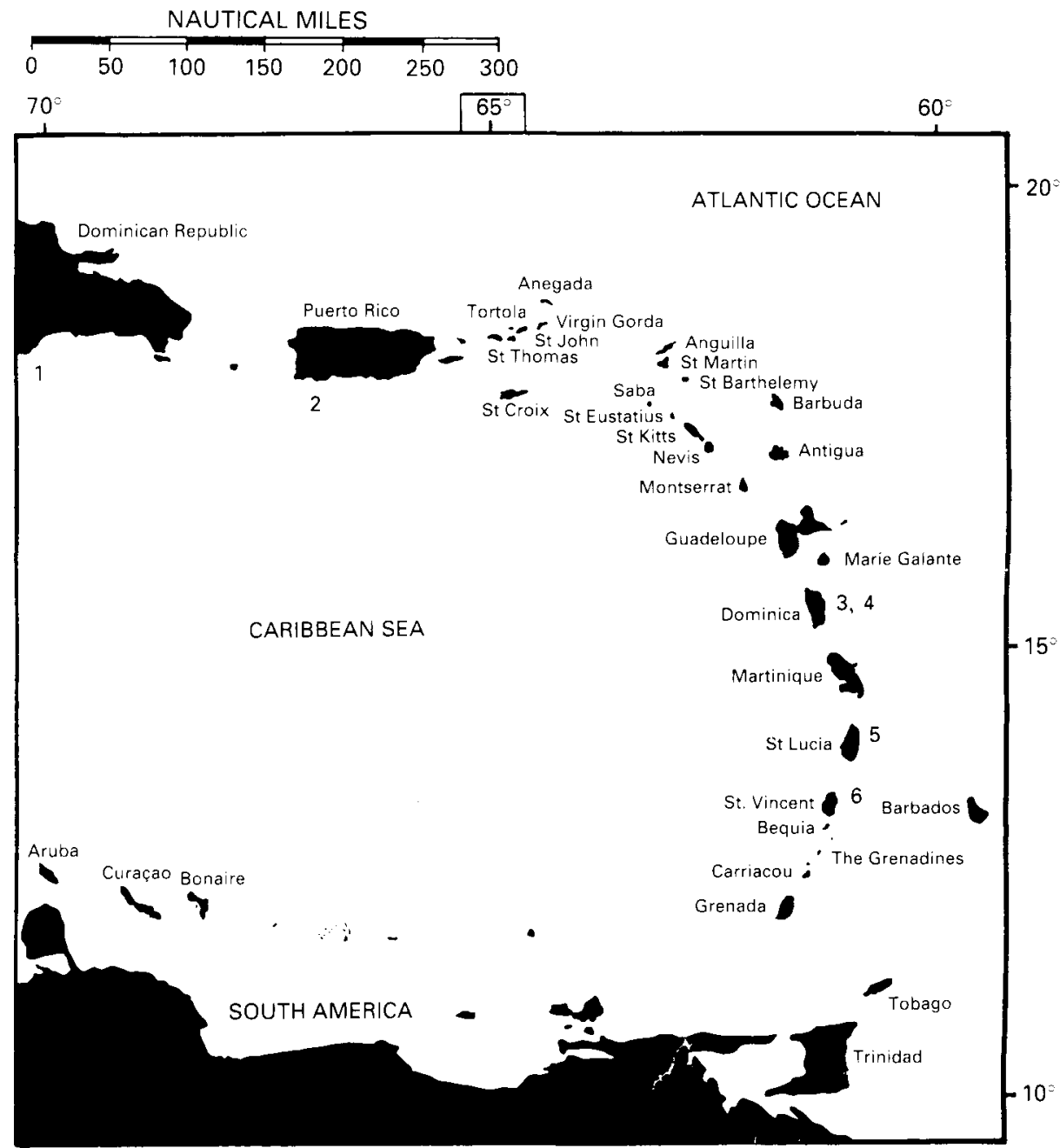

Figure 1. Distribution of Amazona parrots in the eastern Caribbean. 1, A. ventralis; 2, $A$. vittata; 3, A. imperialis; 4, A. arausiaca; 5, A. versicolor; 6, A. guildingii.

During the present century, populations of both Imperial and Red-necked Parrots have shown steady declines, accelerated by Hurricanes David and Allen which caused substantial damage to Dominica's forests in 1979 and 1980 respectively. Both parrots have shown a contraction of range (Figures 2 and 3 ) and their stronghold now resides on the slopes of Dominica's highest mountain, Morne Diablotin $(4,741 \mathrm{ft}$ or $1,421 \mathrm{~m})$. This paper presents the results of a special study carried out on both parrots between 1982 and 1990 as part of a long-term Multiple Land-Use Project established in 1982 to help conserve Dominica's rainforests. 


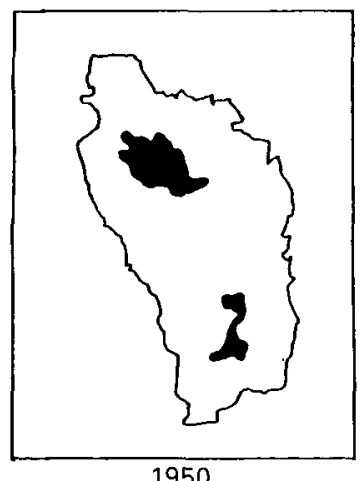

1950

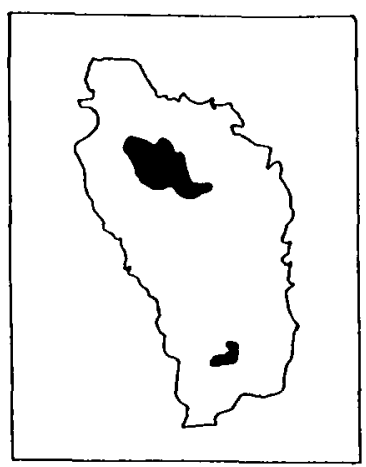

$1975-1978$

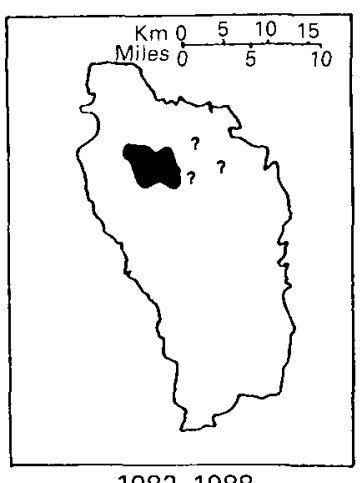

$1982-1988$

Figure 2. Distribution of the Imperial Parrot.

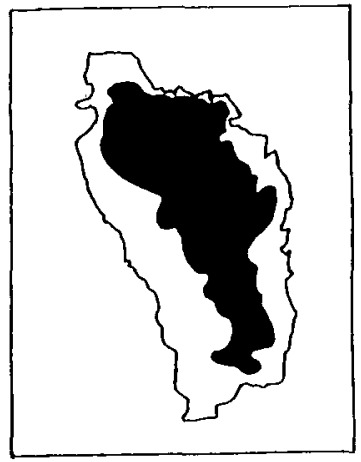

1950

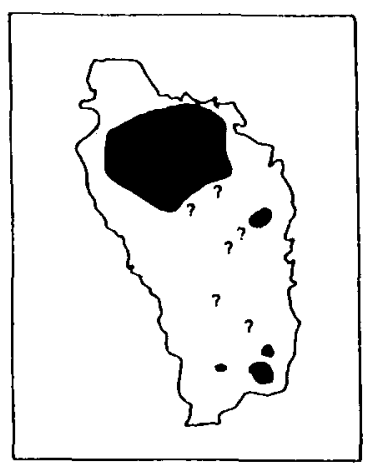

$1975-1978$

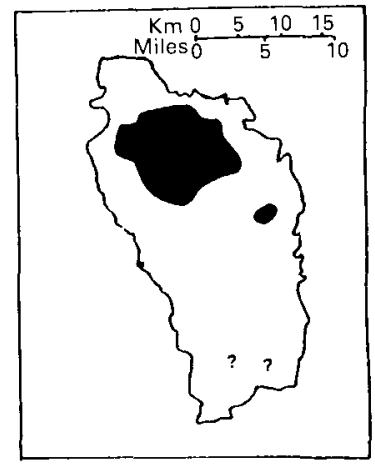

1982-1988

Figure 3. Distribution of the Red-necked Parrot.

\section{Methods of study}

I carried out a preliminary study on the parrots in June-August 1978, prior to the two hurricanes, and have subsequently made 12 visits with teams of biologists of 1-4 months duration. Because parrots are difficult to survey or closely observe in the thickly forested, mountainous terrain that covers two-thirds of the island, special techniques had to be developed. These included the construction of wooden platforms from good vantage points in the forest canopy. They have allowed timed watches to be undertaken where the movements of individual parrots can be plotted on sketch maps or photographs.

By plotting individual movements over a protracted period, it is possible to determine the approximate number of birds inhabiting the study area. The number of registrations and number of separate calls can then be related to the actual population size estimated for that study area. This was repeated at different times of the day because calling and flight activity vary diurnally. From the results of these watches, it was possible to arrive at a set of correction factors for converting the number of calls registered per unit time of observation into an estimated number of birds present in the area. Calls were used in preference to actual sightings since calling was considered to be relatively independent of 
habitat heterogeneity, where variations in visibility were likely to influence detectability of birds.

For monitoring population changes, initial tests were carried out to determine how much observation time was required before the bulk of the population using the study area at the time had been registered. The results showed that if watches were carried out during early morning or late afternoon peaks in activity, $80 \%$ of the local population would be registered after watches of $80-100$ minutes' duration. During the middle of the day when parrots are less active and hence more difficult to detect, watches lasting 130 minutes were required to detect the same percentage of the local population. In the light of these results, it was decided to conduct regular watches of 100 minutes' duration between o6hoo and 1 hoo or 16 hoo-18hoo. The same vantage points were used each visit so that results would be comparable from one year to the next. These allow an index of population change to be determined for both species.

For mapping the relative abundance of Imperial and Red-necked Parrots, the island was divided into $1 \mathrm{~km}$ squares, and surveyed preferably during early morning or late afternoon. The number of registrations was converted into an abundance index using correction values, determined in the manner described above. Parrot surveys were conducted using only personnel experienced in parrot identification since untrained persons often confused the two species when observing them at a distance.

Other parrot studies concentrated upon locating preferred feeding and roosting sites, and making close observations of individuals to study aspects of social behaviour. Potential threats to the parrots were examined in particular detail, together with possible competitive interactions between the two species. Results of the biological studies have been presented elsewhere (Evans 1988).

\section{Status and distribution}

Prior to the present studies, there has been no attempt at a comprehensive census of the total island population for either species, and figures quoted have been no more than informed guesses. Nevertheless, historical accounts do give some rough idea of the relative status of the two species in the past.

\section{The period 1850-1950}

In the nineteenth century, the Red-necked Parrot was considered to be less common and more difficult to find than the Imperial Parrot (Lawrence 1878, 1880, Verrill 1892). However, Verrill (1905) noted that in the interval between his 1890 and 1904 visits to Dominica, the Red-necked Parrot had become much the more abundant species, and this has remained the case ever since. The populations of both species probably numbered a few hundred until about 50 years ago. Porter (1929) reported a Dominican observing a flock of one or two hundred Imperial Parrots following "the terrible hurricane of the autumn of 1928 ". Although the Dominican considered this to be "the entire population of the species", it nevertheless suggests a relatively healthy population size. It is quite possible that the hurricane of 1928 had a substantial impact on the parrots much as the more recent ones of 1979 and 1980 have done. Further south, Howes 
(1929) reported that he saw Red-necked Parrots "several times on (Morne) Trois Pitons" during his ascent of that mountain during early March.

Although no population estimates were made before 1970, the Dominican Forestry Division (1981) considered that in 1918 there were somewhere between 200 and 275 Imperial Parrots and that by 1950 this had declined to $100-150$ individuals. They give no past estimates for the Red-necked Parrot populations.

\section{The period 1950-1975}

Information on the status and distribution of the two parrots in more recent decades of this century comes from local Dominicans, notably the local aviculturist, Daniel Green. He has reported that, around 1950, the Imperial Parrot was distributed not only over a much larger area on the slopes of Morne Diablotin, but also in the south of the island (around Morne Anglais, Geneva area south of Morne Watt, and in the area between Foundland, the Ravine Cacao Valley and Perdu Temps River Valley, as well as occasionally between Robinson Estate and Morne Watt) (Nichols et al. 1976; see also Figure 2). Holly Nichols and colleagues were unable to explore this area thoroughly during their visit in 1975, but did not observe any Imperials there nor hear reliable reports of the species anywhere south of Morne Diablotin except around Morne Anglais where Arnold Green reported seeing fifteen Imperials at one time around 1970.

The Red-necked Parrot had a much wider distribution, and Nichols et al. (1976) reported local Dominicans indicating that around 1930 the species inhabited virtually all the lower elevations of the forested interior, with large foraging flocks congregating near the coast between late August and late October. Daniel Green recollects sighting between 200 and 300 Red-necked Parrots feeding during the "flocking season" up the Indian River, south-east of Portsmouth, as far as it is navigable. In the early 1970s, Holly Nichols and colleagues recorded approximately 5o Red-necked Parrots during the flocking season in this area (Nichols et al. 1976). Nowadays maximum numbers here do not exceed 10-20 individuals. Around 1950, Daniel Green observed Red-necks in an area north-east of Portsmouth bounded by the road between Hansen and La Source, Moore Park Estate, La Source Estate, Trocard, and Reilly Estate. By 1975, they were no longer to be found normally in this area, or anywhere north of the Portsmouth to Anse Du Mé road (Nichols et al. 1976); the same remains true today (Figure 3).

South of the above region, Daniel Green provides further historical information on the distribution of Red-necked Parrots, recalling them occurring around 1950 in a large area between Djerrick (west of Gaulette in the Carib territory), Morne La Source, Morne Fraser, Yellow River, Fond Figues, William, Harris Soltoun Estate (south of Morne Couronne), Bells, California Estate, and Deux Branches (Nichols et al. 1976). Forest Officers reported to Holly Nichols that Rednecked Parrots could frequently be seen (especially between August and October) in neighbouring D'Leau Gommier Forest Reserve, and between Morne La Source and Morne Fraser (north-west of Castle Bruce, west of Richmond Bay). A few were also thought to "probably still exist in the remaining undisturbed forest between Perdu Temps, Fond Figues, Morne Nègres Marons, and D'Leau Gommier" (Nichols et al. 1976). 
In February 1971, when John Terborgh briefly visited the island, he was surprised to find the Red-necked Parrot absent from the area around Morne Trois Pitons despite apparently suitable habitat (Nichols et al. 1976). Although Noel and Helen Snyder also failed to find the species there during a visit in October 1973, they were informed by two local people that one of them had killed four out of a flock of eight birds in the area, and the other had shot two birds. However, in 1975, Holly Nichols and colleagues were unable to find any during visits to Morne Trois Pitons and they have not been recorded there since.

East of Morne Trois Pitons, Daniel Green noted Red-necked Parrots around 1950 between Terre Ferme, Newfoundland and Fortune, and between Terre Ferme, Macaque, Croix (south-east of Morne Trois Pitons, and north-east of Morne Macaque), and about $0.6 \mathrm{~km}$ east of Boeri Lake (Nichols et al. 1976). They were also known by Green in the area between Middleham Estate and Morne Macaque, but by 1975 were considered by Nichols et al. (1976) as "extremely rare there now due to hunting, if they exist at all". Farther east, between Morne Sinai, Grand Soufrière Hills, Rivière La Blanche and Mayambé Estate (west of Délices on the east coast), a few Red-necked Parrots were said to occur (Nichols et al. 1976). Holly Nichols and colleagues had no reliable information for the neighbouring area between Croix, Palmiste (west of Pointe Giraud on the east coast), Grand Soufrière Hills, and Boiling Lake.

Around 1950, Daniel Green had observed Red-necked Parrots in mixed flocks with Imperials around Foundland (between Mayambé Estate and Bagatelle Estate). In 1975, although there was no information from Foundland, Ravine Separée, and the headwaters of the Savane River, Holly Nichols and colleagues (1976) had reports that a few still existed in the heights south of River Jack and in the upper reaches of River Claire; I confirmed this during discussions with older farmers from nearby Délices and Pointe Mulâtre.

On the western slopes of Morne Anglais, Nichols et al. (1976) observed at least four pairs of Imperials, one of which was nesting on the ridge between the upper forks of the River Gillon. Arnold Green also knew of a second nest in the area which had been used in 1974. However, he noted a marked decrease in the Imperial population in the Morne Anglais area, having observed 15 at one time only 5 years previously. Dominican hunters and Arnold Green reported to Nichols that they had never seen Red-necked Parrots on the western slopes of Morne Anglais. However, one of her team, Gustaaf van Vliet, saw a pair there in May 1975.

Nichols et al. (1976) considered that there were somewhere between 350 and 450 Red-necked Parrots and 150-200 Imperial Parrots in the whole of Dominica over the period 1972-1975.

\section{The period 1975-1990}

When I first visited Dominica during June-August 1978, the Red-necked Parrot was common and widely distributed throughout the area encompassed by the Northern Forest Reserve, and extended on all sides of this region down to an altitude of around $500 \mathrm{ft}$ ( $150 \mathrm{~m}$ ). Farther south, although not observed directly, the species was reported by local persons from the vicinity of D'Leau Gommier, Perdu Temps, Morne La Source, and Morne Fraser in the central region and, in 
the south, from the Geneva area (south of Morne Watt) to Perdu Temps River, Foundland and upper River Claire. Searches in the Middleham Estate and western slopes of Morne Trois Pitons revealed no parrots. Imperial Parrots were observed only on the slopes of Morne Diablotin above 1,500 $\mathrm{ft}(450 \mathrm{~m})$, and the only other reports were of a remnant population in a triangle of montane rainforest bordered by the summits of Morne Watt, Morne John, and Morne Anglais.

Estimates of the total Red-necked Parrot population in 1975 had been made by Nichols et al. (1976). Each had a slightly different impression of the total numbers. Gregory Gray thought there were as many as 400 Red-necks and 250 Imperials. Gustaaf van Vliet thought there were between 250 and 300 Rednecked Parrots and no more than 150 Imperials. Holly Nichols herself thought there were around $35^{\circ}$ Red-necks and 150 Imperial Parrots. However, in 1977, Arnold Green described seeing a single mixed flock of $c .350$ on Hampstead Ridge (Snyder and Snyder 1981). Even if this flock estimate was too high, it seems likely that the previous overall figure was too low and the Red-necked Parrot population at that time probably numbered a few hundred individuals. They all agreed that, south of a line between St Joseph on the west coast and Grand Marigot Bay on the east, there were probably less than 50 (perhaps less than 24) Red-necks and 8-10 Imperials.

During my visit to Dominica in 1978 , I concentrated work on the parrots in the region of Syndicate and Dyer Estates, on the north-west slopes of Morne Diablotin. Here, both species were common with flock sizes reaching maxima of 20 Red-necks and six Imperial Parrots. Although Imperial Parrots occurred mainly on the higher slopes of Morne Diablotin, they would regularly come down to the edge of the Syndicate Estate to roost in late afternoon, and would feed on Dacryodes and Sloanea trees there. Previously, Nichols et al. (1976) had observed only two Red-necked Parrots during visits to Syndicate Estate, and Imperials were seen above the estate at an elevation of about $2,200 \mathrm{ft}(670 \mathrm{~m})$ on the steep north-western slopes of Morne Diablotin. Elsewhere, Nichols and colleagues had found the highest densities on Simpa Flats (south and west of Torenté and Never Fail, on the north-eastern slopes of Morne Diablotin). Here, they had seen at least a dozen Red-necked Parrots each morning, and observed 10 Imperials together with two Red-necks feeding in a single Euterpe palm tree. I did not visit this area in 1978, but surveys of the region since then have shown densities of Imperial Parrots comparable with those found on the north-western slopes, although densities of Red-necked Parrots have been lower.

On 29 August 1979, Hurricane David swept through Dominica, causing devastation in its path. It travelled in a south-east to north-west direction, causing greatest destruction to the southern part of Dominica, particularly around the slopes of Morne Trois Pitons, Morne Watt, and Morne Anglais. In this region an average of $50 \%$ of all trees were damaged, and Lugo et al. (1983) estimated that altogether a total of about five million timber trees had been damaged in the southern third of the island. Although both parrot species were seen in the southern part of the island in the year or two following the hurricane, since 1982 there has been no verified sighting of an Imperial Parrot in the area, and only occasional scattered sightings of Red-necked Parrots.

Hurricane damage, though greatest in the southern portion of the island, was 
not restricted exclusively to that region. No part of the island escaped at least some damage, even on the leeward slopes of Morne Diablotin. When Noel and Helen Snyder visited Dominica in October 1979, they concentrated on assessing the effects of the hurricane on the central and southern forests. Later that month, Tom Nichols also visited the island but concentrated his efforts in the north of the island - in the Bense Valley, and the Picard Valley including neighbouring Syndicate and Dyer Estates (whick. Nichols refers to as Devil's Valley). Both sets of workers found that even two months after the hurricane the once lush forest was stripped bare of all leaves and small branches, with no signs of fruit. Nichols (pers. comm.) describes Dominicans being able to catch parrots by simply walking up to them. Some parrots were thought to have been captured, and either kept in captivity or sold as pets. A few were handed over to the Forestry Division to care for. It was generally thought that the forests had been severely damaged, and that the Imperial Parrot population had seriously decreased. On the basis of that brief visit, Tom Nichols considered that there were less than 75 Imperial Parrots remaining (Nichols 1981). He returned to Dominica with Alphonso Nichols in June 1981, some months after the second tropical cyclone, Hurricane Allen, had struck Dominica in September 1980. They again visited the Dyer and Syndicate Estates. In the mid-1970s, Holly Nichols and Alphonso Nichols had discovered five nest-sites in the area. Two of those trees were now iotally destroyed, and the remainder were not being used. They also observed that large tracts of forest were being clear-cut for the planting of bananas. Their revised population estimate was $40-60$ Imperial Parrots (Nichols 1986). However, this estimate must be regarded with some caution since, besides the difficulty of obtaining an accurate census, only a small portion of the species's range was visited.

In 1978, and every year since 1982, I have monitored numbers of Red-necked and Imperial Parrots in the Upper Picard Valley, on the north-western slopes of Morne Diablotin, one of the areas where numbers of both species are concentrated (Figures 4 and 5). The results indicate a substantial decline in the population sizes of both species after Hurricanes David and Allen (see Figure 6). The total populations were estimated in 1987 at $\mathcal{C} .200$ Red-necked Parrots and $c$. 6o Imperial Parrots (Evans 1988). However, in the last two years, the Red-necked Parrot populations have been showing signs of recovery, with an expansion of their range. Red-necks which disappeared from some of the lower-lying areas on the edge of plantations in the north and north-east of the island are now returning to those areas, and parrots are being seen increasingly south of the road that crosses the island from Pont Cassé to Marigot, in the forests on the slopes of Morne La Source and Morne Fraser, and in the Maclauchlin area. There is little sign yet of the species returning to the slopes of Morne Trois Pitons o: further south. In the Upper Picard Valley itself, numbers increased between 1987 and 1989 but since then have actually declined. On the other hand, in neighbouring Dyer, Syndicate and Morne Plaisance Estates, Red-necked Parrots have become much commoner, and there is some indication that the species has been moving back into lower-lying areas, often on the edge of banana plantations. The latest total island estimate (May 1990) is of c.300 Red-necked Parrots.

The Imperial Parrot showed no evidence of recovery until very recently. Timed watches and surveys in April-May 1990 indicate a marked increase in 


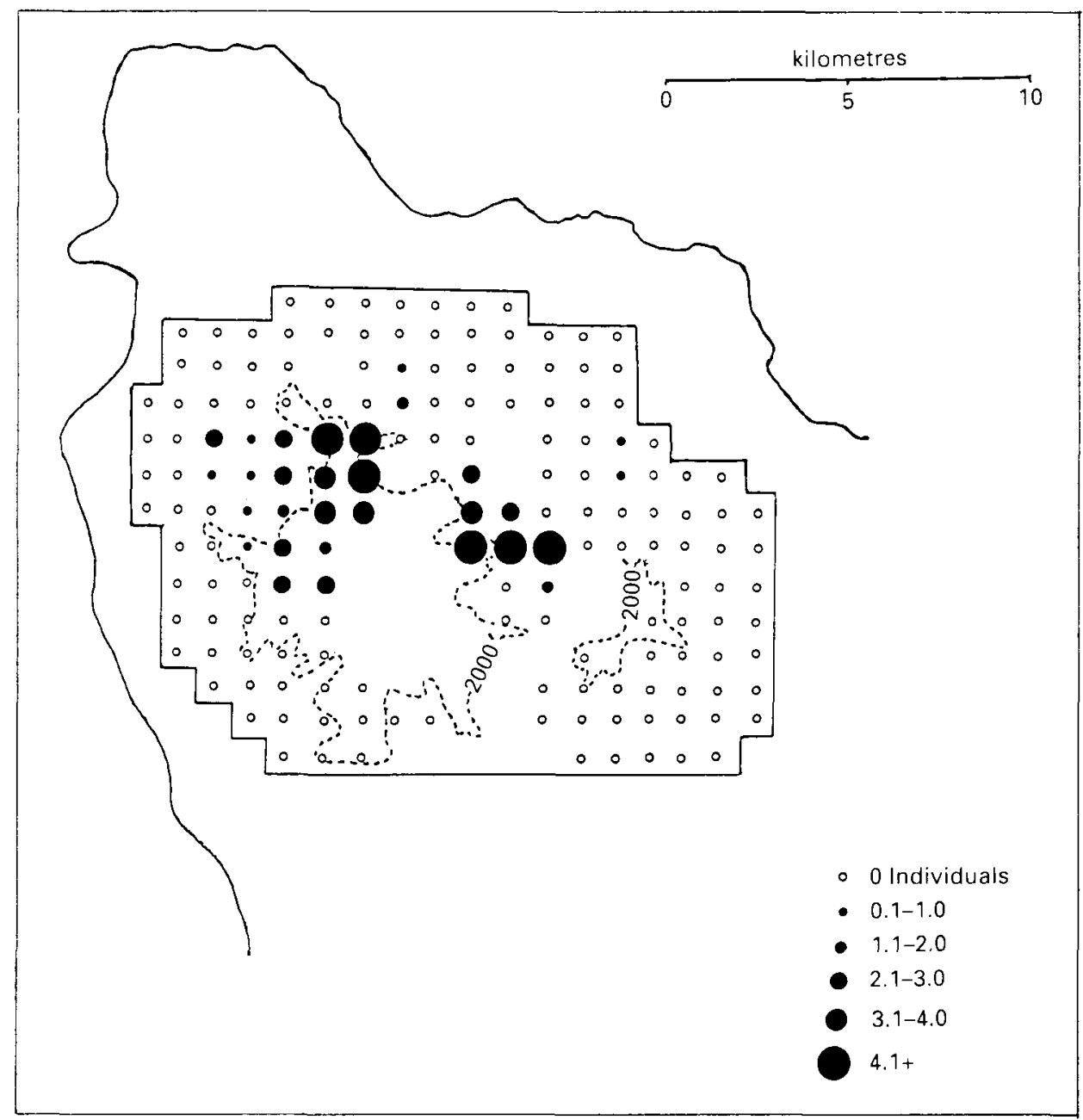

Figure 4. Relative abundance of the Imperial Parrot during the 1980 s.

numbers now occupying the Upper Picard Valley, and the return of the species to the Syndicate and Morne Plaisance Estates where it had been virtually absent for 10 years. Flock sizes of Imperial Parrots, which since 1982 had never exceeded three individuals, are currently showing maxima of double this amount, and during one of five 10o-minute watches in the Upper Picard Valley in April 1990, a total of 18 separate individual Imperials were recorded. This bodes well for the future, so long as these regions can be afforded protection. The current total island estimate is of $c .80$ Imperial Parrots.

\section{Threats}

Four major potential threats are recognised. These are: hunting (for food and the captive bird trade), habitat destruction, natural and introduced predators, and interspecific competition between the two parrots. They will be considered in turn. 


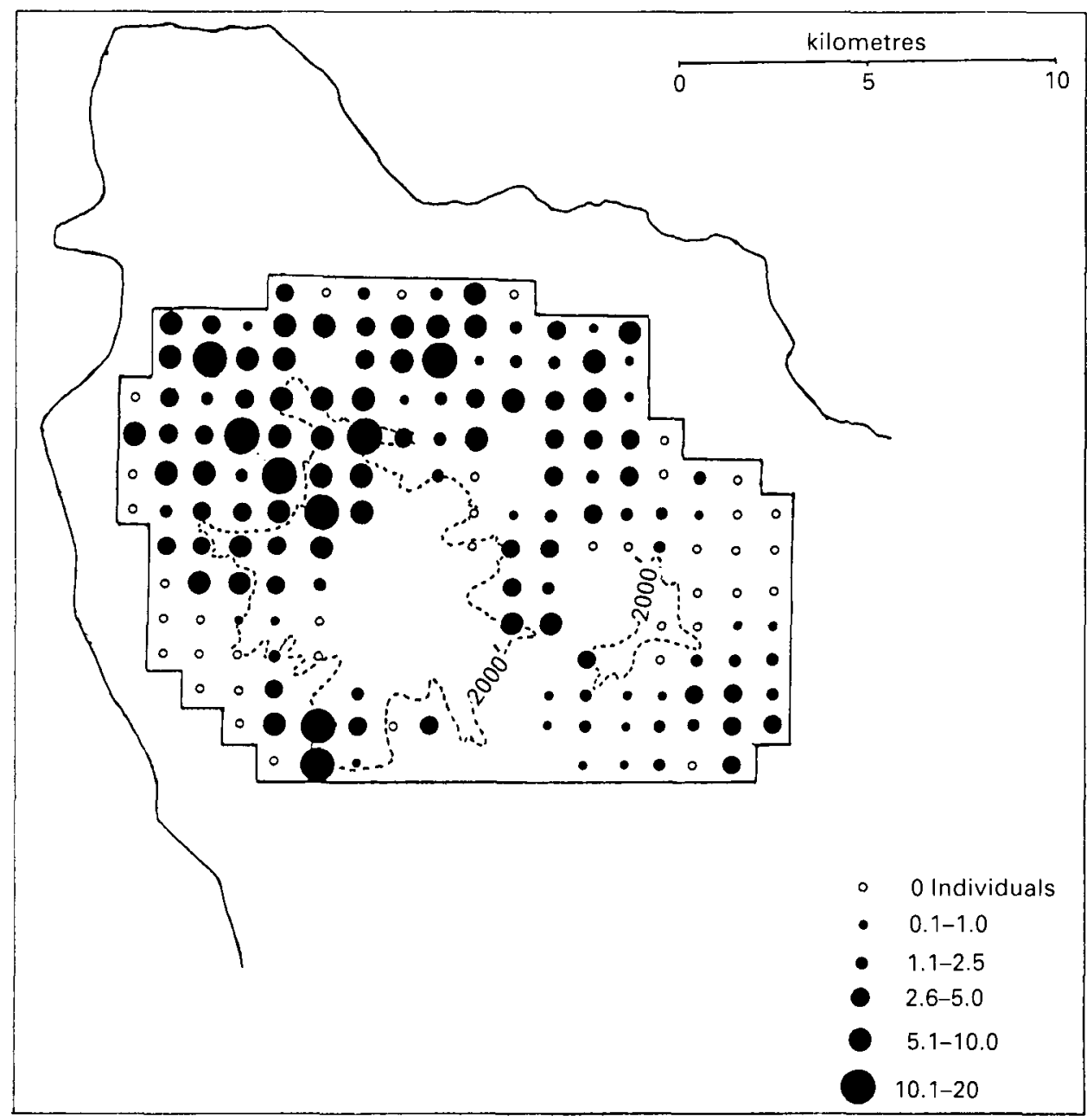

Figure 5. Relative abundance of the Red-necked Parrot during the 1980s.

\section{Hunting}

Many earlier visitors to Dominica have described how both parrot species were commonly hunted for their meat (see, for example, Ober 1878, Porter 1929, Nichols et al. 1976). Porter (1929) noted a total of over 38 Imperials killed and captured during a period of five months in 1928-1929. Declines in both species earlier this century were attributed by Nichols et al. (1976) to greater access by hunters to previously remote forested areas. The problem was made worse by the widespread use of firearms with licences being easy to acquire for the hunting of wild pig and agouti but which then facilitated the uncontrolled hunting of other species. As the Imperial in particular became very rare, there was further pressure from the captive bird trade with high incentives to purchase birds. As recently as 1976, Alphonso Nichols was informed how in response to an offer of a large sum of money by a foreigner, a local hunter had 


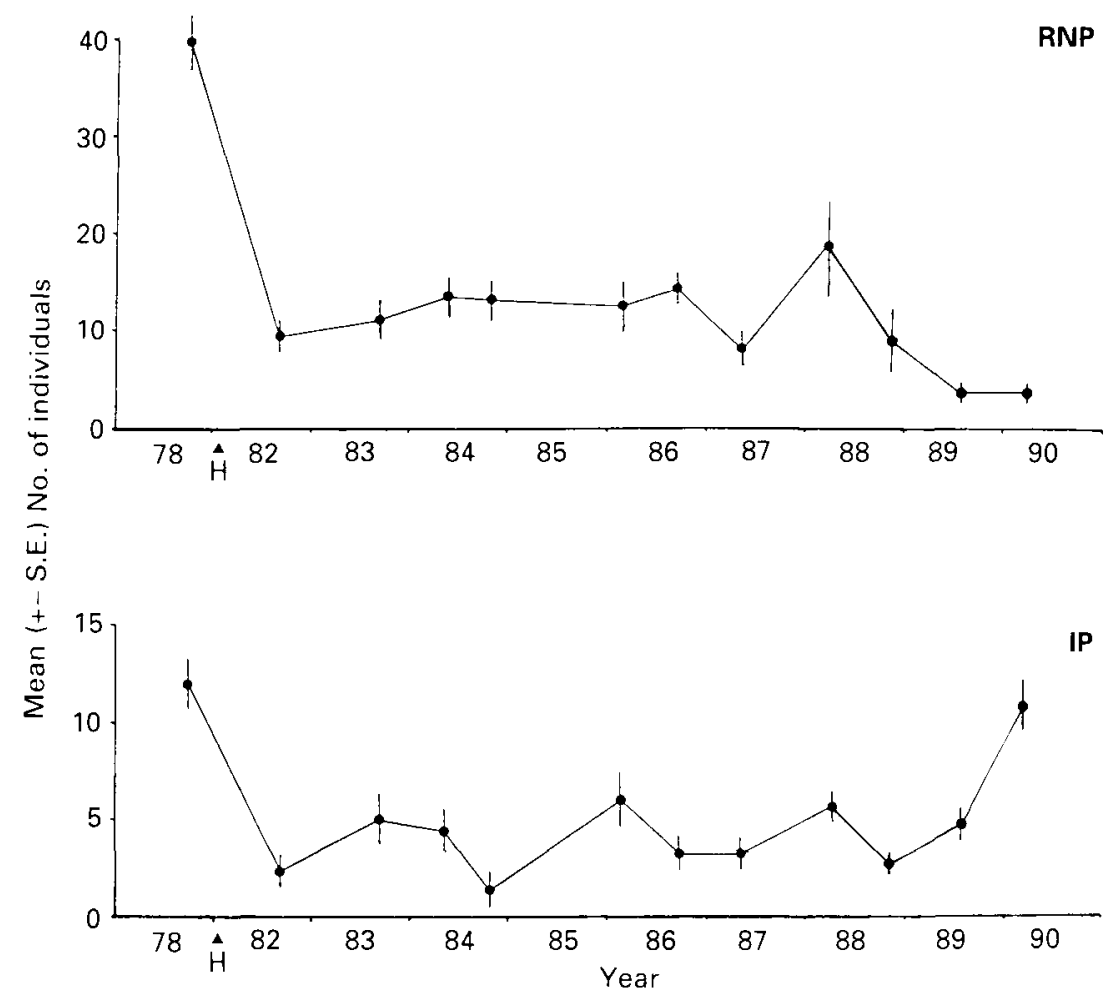

Figure 6. Populations of Red-necked Parrot (RNP) and Imperial Parrot (IP) in the Upper Picard Valley 1978-1990. $\mathrm{H}=$ Hurricanes David and Allen. Note that the recent RNP decline has been accompanied by increases in adjacent lower-lying areas.

shot 15 parrots in a single Dominican valley (Nichols 1986). The customary method for obtaining parrots alive is to wing them with shot, but this hunter apparently failed entirely in this attempt, ending up by killing all of them. During that year, the Forestry and Wildlife Act (Act No. 12) made it illegal to hunt parrots under any circumstances, whilst the National Parks and Protected Areas Act (Act No. 15), passed in 1975, forbade hunting in all legally established national parks. The latter does not apply to forest reserves where both parrot species are concentrated, but at least it afforded protection to Morne Trois Pitons National Park where the two species once occurred but had been suffering heavily from human exploitation.

Many past accounts of the Imperial Parrot relate to the extent to which it was hunted. Verrill (1892) reported that "they are much hunted for food during the time the game law is off, being then occasionally for sale in the market at Roseau, consequently, though common in particular localities where they live, they are exceeding shy and difficult to procure." Porter (1929) gives a similar picture: "I regret to say that when they [Imperials] stray away from their natural home the birds are still shot by the native gunners now and then for food. This is a great shame, for I hear that the flesh of these birds is very tough and leathery ... It is a great pity that they are eaten, but the natives have no idea of the rarity of the species ... The greatest danger now lies in the fact that the two edible mammals of the island, the wild pig and the agouti are, owing to persistent 
persecution, getting very scarce, and the natives are penetrating into the home of the Imperial Parrot. If they are unlucky, as they often are, in failing to obtain either of these animals, they shoot the Parrots. Native hunters told me that they are not coming back empty-handed when there are 'Ciceroo' about. So to some extent the fate of the birds depends on the fate of the two mammals."

Although most historical accounts single out the hunting of Imperials, it is likely that the Red-necked Parrot was also hunted extensively. On the other hand, it is interesting to note that previous visitors to the island and present observations all highlight how much shyer and more wary of humans is the Imperial Parrot. This has sometimes been attributed to their less frequent contact with humans since they live higher up in mountain forests. However, it may actually reflect greater hunting pressure.

After Noel Snyder's visit to Dominica in October 1973, he reported to Holly Nichols that "essentially everyone we talked to on the island acknowledged that he formerly or presently hunted parrots, including the taxi driver who took us from the airport to Roseau and our principal contacts on the island ... Several people commented that the parrots were very easy to shoot (once found)" (Nichols et al. 1976). Noel Snyder also highlighted another problem, the lack of law enforcement, stating that "hunting of parrots, though illegal, is socially acceptable and might as well be legal". Nichols et al. (1976) concluded that "all our observations and all of the current reports we have heard from Dominicans themselves lead us to conclude that hunting is still by far the most serious threat to the two remaining parrot species".

Happily, over the last 15 years, the situation with respect to hunting has changed considerably. This has been due in no small measure to the efforts of the Dominican Forestry Division. They not only pressed for the passing of new legislation to protect the parrots, but have regularly patrolled relatively remote areas to enforce those laws vigorously, whilst at the same time launching an intensive education campaign. These activities developed particularly after the damage caused by Hurricanes David and Allen in 1979-1980, under the directorship of Christopher Maximea and, with his retirement, have been continued by Felix Gregoire and his staff of well-trained, conservation-minded foresters. With grant support from WWF, the Forestry Division visited over 50 schools in 1980 to educate children in the importance of wildlife, especially the two parrot species. A 30-minute conservation programme was started weekly on the radio, and a play entitled "Parrot Poachers" highlighted the undesirability of hunting. Nearly 2,500 forest patrols were also undertaken in the 12-month period to protect and survey the parrots. These identified that hunting was restricted almost entirely to game animals, particularly agouti, opossum and wild pig, and took place mainly at lower elevations due to lack of trails and inaccessibility of the forest following Hurricane David. A total ban on the hunting of all birds (later extended to all wildlife) had the desired effect of protecting the parrots from all but the most notorious parrot poachers (Forestry Division 1981).

The temporary ban on the hunting of all game animals was enforced after the hurricanes to give populations a chance to recover. This meant that anyone carrying a gun was automatically identified as acting illegally. Recently, the law has been relaxed so that the hunting of wild pig, agouti, and Red-necked Pigeons Columba squamosa may take place between the beginning of September and the end of February (i.e. outside the main breeding season). Nevertheless, 
the hunting (capture, sale or illegal possession) of parrots is forbidden and carries a penalty of $\mathrm{EC} \$ 5,000$ fine and three years imprisonment. It is vigorously enforced by the Protection Section of the Forestry Division.

In the last 10 years, the climate of feeling amongst Dominicans with regard to bird conservation has changed markedly, partly as a result of strong educational campaigns mounted by the Forestry Division with support from RARE Center for Tropical Bird Conservation, the International Council for Bird Preservation (ICBP), and the World Wildlife Fund - U.S. (WWF). The Imperial Parrot is now regarded by the government as the national bird, and is integrated into the country's coat of arms and the national flag, after Dominica's independence in 1978. A conservation education newspaper "VWA Diablotin" was started by U.S. Peace Corps volunteer Randy Macdonald in 1983 and circulated to every school child on the island. Unfortunately, lack of resources prevented it continuing beyond a couple of years. However, after a gap of five years, it has been started again by the newly formed Environmental Education Unit, run by Forest Officer Arlington James with strong support from Ronald Charles. It now appears every month as a supplement to the national newspaper the New Chronicle.

Conservation education in Dominica received a further major boost in January 1989 when Paul Butler of the RARE Center for Tropical Bird Conservation started an eight-month programme on the island to heighten public awareness of the plight of the two parrots as part of "Project Sisserou" (Butler 1989). This involved distributing a questionnaire to ascertain current awareness, visits to all the schools, distribution of posters of the two parrots, local fund-raising activities, and cultural events including a musical performed by the Kairi School of Music. An amnesty on the possession of captive parrots was instigated during which persons could retain their parrots so long as they registered them and kept good care of them; each was given a numbered steel leg band, which will help to identify any future illegal capture of parrots. During the amnesty period (February-March 1989), five individuals came forward and registered a total of eight Red-necked Parrots and one Imperial Parrot. For the safe keeping of confiscated parrots, at the same time enabling local people to see parrots at close quarters, proposals were also made for the construction of an aviary in the Botanical Gardens in Roseau. In preparation for this, Ronald Winston of the Forestry Division took part in a captive breeding course during summer 1990 at the Jersey Wildlife Preservation Trust, with their kind sponsorship.

Despite the efforts outlined above, attempts by unscrupulous foreign bird collectors continue, and it is very important that the government of Dominica maintains a strong vigilance to stamp out further capture and export of birds and specifically becomes a signatory of CITES. Several courses of action are currently being taken to strengthen this vigilance. In the meantime, all responsible aviculturists should unite in efforts to identify and penalise those amongst them who are bringing their pursuit into disrepute.

\section{Habitat destruction}

The continued presence of two species of parrots on the island of Dominica is almost certainly due in part to its very fine rainforests, undoubtedly the best in the Caribbean, with a diversitv of woodv plant species comparable per unit area 
to some sites on the mainland of Central and South America (Evans 1986). Large-scale forest destruction in Dominica is a very recent phenomenon. It is estimated that in the last 10 years a greater area of forest has been destroyed than in all of the previous thousand years (Evans 1989). This accelerating forest clearance is due to a number of factors.

When Hurricanes David and Allen caused extensive damage to the forests of Dominica, this not only had a direct impact upon the parrots by imposing shortterm food shortages and loss of nesting trees (Snyder and Snyder 1979, Nichols 1981, Forestry Division 1981, Gregoire 1981), it also had several indirect effects which in the longer term are probably more serious for the parrots. First, those areas that were badly damaged provided opportunities for farmers to clear and cultivate the land. This has meant that natural succession of the vegetation back to climax forest has been prevented. Many areas in the south of Dominica which once held parrot populations are unlikely to be recolonised because they have already been cleared for agriculture. Second, following the hurricanes there have been a number of foreign aid programmes, some of which have been devoted to road building and repair, and others to improving agricultural development by providing subsidies for fertilisers, better packaging of fruits and more effective marketing of products. These efforts are obviously to be welcomed since they undoubtedly improve the country's economy and the standard of living of the ordinary person. However, they need careful handling to ensure that longer-term environmental consequences of rainforest clearance are minimised.

At present, bananas are by far the most important agricultural crop, accounting for approximately 70 per cent of all exports and employing more than half of those people working in the agricultural sector (Evans 1986, Central Statistical Office 1988). Bananas grow best in areas of moderate to high rainfall, and this coincides with the bulk of land presently under forest. The recent construction of new feeder roads and improvement of existing ones have opened up many previously remote areas of forest. Small-scale forest clearance is a widespread activity throughout Dominica. The Northern Forest Reserve $(22,000$ acres or 8,800 ha) encompasses most of the present range of both Imperial and Rednecked Parrots (Figures 4, 5 and 8). However, some important areas of forest for parrots lie outside the reserve and are rapidly being cleared, mainly for agriculture. Most important of these are the Syndicate, Milton, Jude and Morne Plaisance Estates in the north-west; the ridges on either side of the Hampstead River in the north; the area that includes Grand Bambou, Subaina and Constant Spring, the upper reaches of the Melville Hall River, and the lower slopes of Morne Concorde, in the north-east. All these areas are unprotected, lying just outside the Northern Forest Reserve, but concessions have also been granted to NorthEastern Timbers Ltd, based at Woodford Hill, for controlled logging of 50 acres (in five 10-acre blocks) of the forest reserve between Hampstead Ridge and Grand Bambou.

At present, Morne Trois Pitons National Park is the only national park in the interior of Dominica. Although it is a valuable centre of attraction for tourists, with its natural features such as Boiling Lake, Emerald Pool, Boeri and Freshwater Lakes, Titou Gorge, and Trafalgar Falls, it does not have such fine forest nor as rich wildlife as those within the main Morne Diablotin mountain massif. 


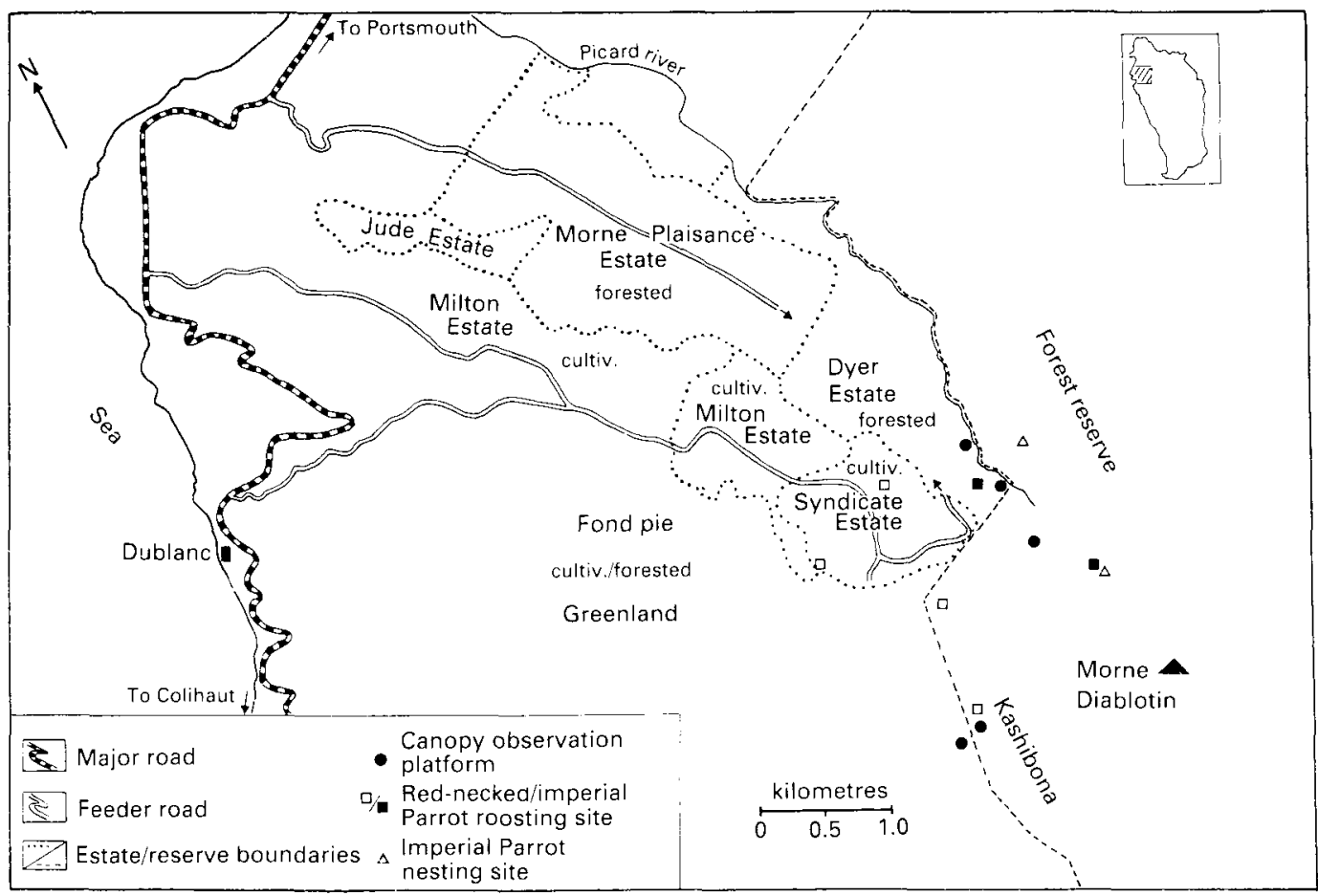

Figure 7. The Morne Plaisance and Dyer estates.

This is due in part to its greater susceptibility to hurricane damage since it lies more directly in the track of hurricanes, which usually come from the south or south-east. It is probably also due to the more nutrient-rich allophane latosols that form the soils of much of the northern region, and the longer history of cultivation by man in areas like the Roseau and Layou Valleys.

Two forested areas, important to parrots yet threatened with clearance, have attracted recent attention. The first of these is the Morne Plaisance Estate, an area of 928 acres ( 375 ha) lying on generally flat land north of Morne Diablotin at between 900 and $1,500 \mathrm{ft}(285-465 \mathrm{~m}$ ) (Figure 7 ). In 1982, Rotary Timbers Ltd acquired rights from the owners, Geest Industries, to clear-fell parts of the forest prior to the leasing of those lands and the neighbouring Dyer Estate to small farmers as part of an economic development plan for the region. Concern was expressed by the Forestry Division that logging operations could have a detrimental effect on parrots since Red-necks used the area extensively for feeding, also roosting and even nesting there (Zamore 1982). Michael Zamore recommended that forest land bordering the south side of the Picard River (mainly within the Dyer and Constant Spring Estates, but also extending into the Morne Plaisance Estate) be left undisturbed to protect the water catchment; a similar band of forest alongside the Espagnole River should also be protected for water conservation and to act as a buffer to enable movement (feeding) of Rednecked Parrots from Morne Plaisance to Milton Estates. Light selective logging was recommended for a band of forest extending from Morne Plaisance to the upper end of the Dyer Estate. This recommendation was a compromise to total 
protection on the basis that this might not be compatible with the government's agriculture policy.

Rotary Timbers started logging in Morne Plaisance Estate in areas identified as least ecologically damaging by the Forestry Division (Zamore 1982) and by Paul Butler (1982) in an independent review funded through the Dominican government by the Canadian International Development Agency (CIDA). As pressures increased for the clearance of neighbouring lands within the Dyer Estate, the Director of Forestry and Wildlife, Christopher Maximea, recommended that almost the entire area be acquired by government and be reserved to protect both the water catchment and the parrots (Maximea 1983). I was also asked to provide a review of the major arguments in favour of complete protection of the area, with recommendations for the setting up of a visitors' centre and research base (Evans 1987). It had long been an aim of the Forestry Division that a nature reserve (to be entitled the Morne Diablotin Nature Preserve) be set up, to encompass approximately 17,000 acres of forest on the slopes of Dominica's highest mountain (Gregoire 1981). Maximea visited conservation organisations in both Los Angeles and Washington during 1983 in an attempt to raise \$2 million to purchase the necessary estate lands. Sadly for the parrots, those pleas were unsuccessful. I also attempted to raise the necessary funds with support from ICBP as well as concerned individuals, particularly Rosemary Low and Tom Nichols. I filed an application for funding support for this proposal to RARE Center in 1987. Following this, representatives of RARE Center visited the island, and subsequently entered into a joint proposal with ICBP to raise funds for the parrots under the title "Project Sisserou". Most urgent was the need to raise $\$ 80$, 000-100, 000 to purchase 204 acres of land adjacent to the Picard River (encompassing the Dyer Estate, see Figure 7), where pressures to log the area were building up from farmers leasing the land from Dominica Fruit Syndicate, and from Dominica Timbers Ltd.

On 20 August 1988, a memorandum of agreement was signed between ICBP, RARE Center and the Government of Dominica to work towards protecting the forest of the Picard River watershed. The agreement was to run initially for a period of two calendar years. In the meantime both ICBP and RARE Center worked towards raising the necessary funds. The National Federation of British Zoos mounted a fundraising campaign on behalf of the Dominica parrots, entitled "Parrots in Peril" during National Zoo Month in June 1988. At the international parrot conference held at Loro Parque, Tenerife, in 1988, further funds were donated towards the project by concerned aviculturists. Between 1987 and 1989, Rosemary Low and Tom Nichols also publicised the plight of the two parrots and donated funds, whilst various bird gardens including Loro Parque raised money through collecting boxes. These funds were sent to ICBP and formed a major contribution to the impending land purchase. My continued research activities were generously supported by various organisations, notably ICBP, the American Federation of Aviculture, and Fauna and Flora Preservation Society. Meanwhile RARE Center was also raising funds. A large grant from the MacArthur Foundation enabled Paul Butler to spend eight months on Dominica during 1989 in a conservation education and local fundraising campaign, whilst RARE Center Trustee Mandy Walsh played a major role in the provision of funds for the urgent land purchase. 
In July 1989, Dominica Timbers Ltd had already moved into the Dyer Estate and was selectively felling gommier Dacryodes excelsa, one of the most important food and nesting trees for both Imperial and Red-necked Parrots. By the end of the month, fourteen large trees had already been felled, and skid trails were penetrating well into the Dyer Estate towards an area particularly important for Imperial Parrots. Then, in the nick of time, the combined efforts of the government, Forestry Division, RARE Center, ICBP, and the people of Dominica saved the day. The intensive education campaign spearheaded by Ronald Charles of Forestry Division and Paul Butler (RARE Center) had raised public awareness of the urgent need for funds, and resulted both in small local donations and in a petition signed by nearly 6,000 children stating that they supported all efforts by the government to try to save their Sisserou parrot. Dens Shillingford, on behalf of Dominica Fruit Syndicate, made a generous last-minute donation of 59 acres of land, and the government contributed the balance of funds enabling the amounts raised by ICBP and RARE to be sufficient to acquire the land immediately.

On 26 July 1989, an agreement was signed with Dominica Fruit Syndicate which placed the 204 acres of land in the joint hands of government, ICBP and RARE Center for a period of three years, subsequently to pass to the government to be used as a nature reserve for the long-term protection of both Imperial and Red-necked Parrots and their forest habitats. Logging activities were to be suspended by the end of August and the timber company relocated on neighbouring Morne Plaisance lands.

Since then, a funding proposal for the development of a Morne Diablotin National Park has been prepared by Gaie Mendelssohn, on behalf of the Dominican government and ICBP, and in close conjunction with the Forestry Division, Paul Butler (RARE Center), and myself (representing ICBP). This proposal, costing approximately $\$ 2$ million, includes plans for surveying boundaries of the proposed park, building a nature centre (with research and interpretive facilities), trails, observation towers, and the necessary infrastructure in the form of roads and car parks for a comprehensive development of the area for wildlife protection, conservation education, ecotourism, and applied research on wildlife and agroforestry. The proposed national park (which includes the 204 acre parrot reserve) covers 6,375 acres on the slopes of Morne Diablotin (Figure 8). It represents not only the most important area for the two parrot species (see Figures 4 and 5), but the best tracts of forest with the richest wildlife in the entire country. As forests inevitably fall to land-hungry farmers, much of the long-term future for both Imperial and Red-necked Parrots will depend upon the success of this ambitious project.

\section{Natural and introduced predators}

Nichols et al. (1976) were the first to draw attention to the potential effect of interference, competition and predation by the Pearly-eyed Thrasher Margarops fuscatus. Nichols had previously observed parrots and Pearly-eyed Thrashers competing for nest-sites on St Lucia with four nesting attempts apparently failing as a consequence. Noel Snyder and J. D. Taapken (1978) and, later, Jim Wiley (1981) had documented similar harassment by thrashers of the nesting 


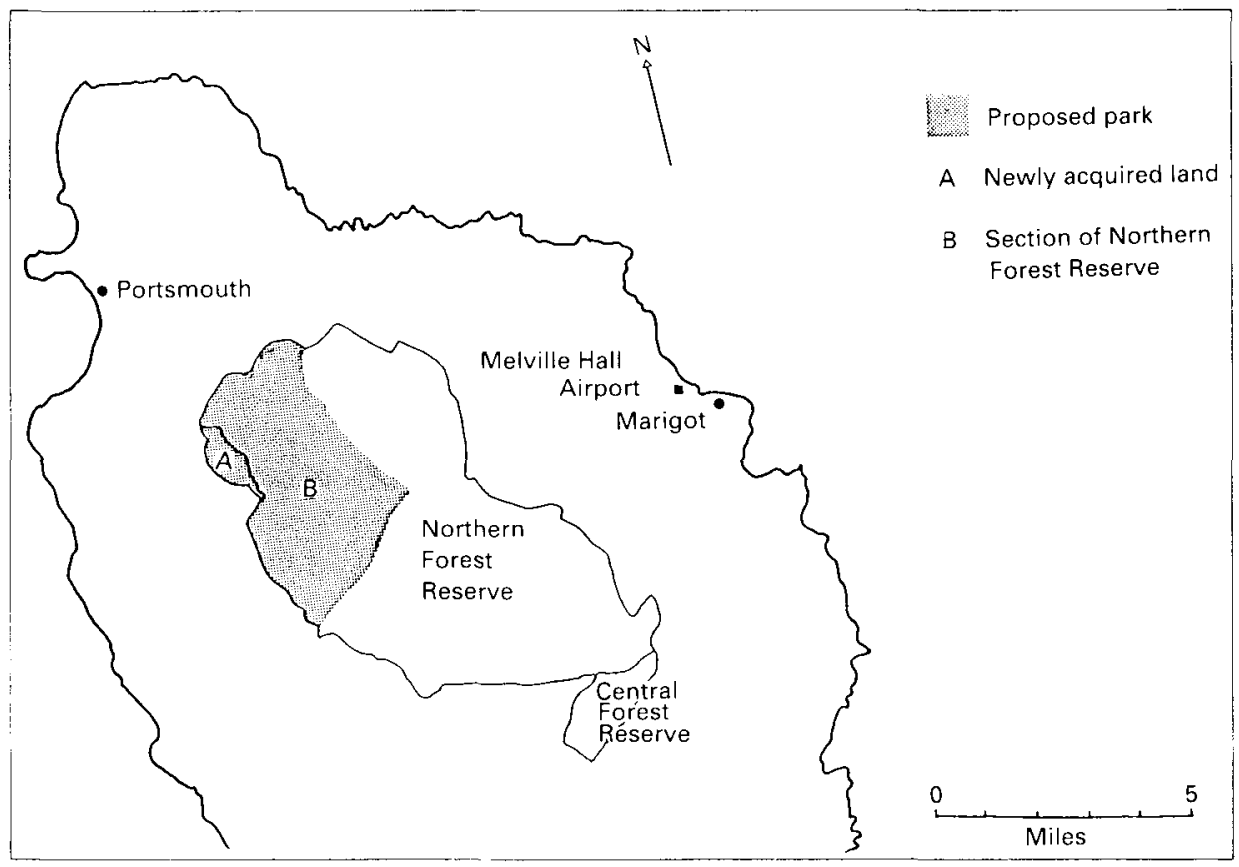

Figure 8. The proposed Morne Diablotin National Park.

attempts of Puerto Rican Parrots. In Dominica, Holly Nichols noted harassment by thrashers at two parrot nest-sites near Hampstead Valley, and in both cases the site was vacated by the parrots in favour of the thrashers, which subsequently laid a full clutch of eggs in at least one of the nests. Forestry Division personnel have also recorded Pearly-eyed Thrashers persistently entering nest cavities of Imperial Parrots despite being repeatedly chased off by the parrots (Forestry Division 1981). Clearly they represent a threat to parrots and this may become increasingly important as suitable nesting sites are reduced by forest clearance. At present, however, the Pearly-eyed Thrasher occurs at relatively low densities in these regions, and so is not considered to be a major threat.

The Broad-winged Hawk Buteo platypterus has in the past been implicated as a potential predator of parrots, and local people commonly suggest that the species preys on juvenile parrots. Nichols et al. (1976) observed only one avoidance reaction of a pair of Red-necked Parrots. Evans and Grieve (1978) observed two interactions. On the first occasion, 12 Red-necked Parrots were seen preening themselves and each other in Anacardium occidentale trees. A Broad-winged Hawk flew over and all the parrots took off with many alarm calls, circled the area and then flew away. They returned about 10 minutes later but the hawk was still perched in the tree so the parrots flew off again. After the hawk had departed, four parrots returned to the same tree. The second incident involved a parrot feeding upon Dacryodes fruits. A Broad-winged Hawk, which had been circling round the area for a few minutes, suddenly flew at the parrot. The parrot flew out of the tree, calling very loudly. Five other Red-necked Parrots flew out of nearby trees and mobbed the hawk, giving alarm calls all the time. The 
attacked parrot went into a Dacryodes tree while the other five parrots chased the hawk up the valley; they then returned to the Dacryodes trees. Since then, despite very many observations of parrots in the vicinity of Broad-winged Hawks, no interactions besides avoidance behaviour or alarm calls have been noted. On the other hand, insufficient time has been spent on the island when recently fledged juveniles would be around. Thus one cannot exclude the possibility that some are predated by hawks. The Forestry Division report (1981) noted at least one account by an ex-hunter of a Broad-winged Hawk pursuing two Red-necked Parrots. They were not able to substantiate any hawk attacks themselves but did note that hawks would peer into tree crevices, presumably looking for chicks. No attacks were observed at the two Imperial nesting sites they had under observation.

Other possible predators include the Scaly-breasted Thrasher Margarops fuscus, opossum Didelphys marsupialis, rats Rattus rattus and $R$. norvegicus, and boa constrictor Constrictor constrictor. Scaly-breasted Thrashers have been occasionally observed displacing parrots at feeding trees (Evans and Grieve 1978, Evans 1988). However, neither this species nor the others are thought to be important predators. Although Nichols et al. (1976) listed all but the first as possibly predating the eggs and/or young of parrots (the opossum having been observed taking St Vincent Parrot eggs and nestlings and St Lucia Parrot nestlings), they had no substantiating evidence from Dominica. Likewise, neither the Forestry Division (1981) nor ourselves have either seen or been informed of such instances. If they do occur, it seems unlikely that they have an important effect on the species.

\section{Competition between Red-necked and Imperial Parrots}

The possibility exists that these two closely related parrot species compete for nest- and/or feeding sites. Both use the same tree species both for nesting and for feeding (Evans 1988). The fact that Imperial Parrots occur at predominantly higher altitudes than Red-necked Parrots suggests that one species may have a competitive influence on the other. This is supported by reports that during this century there may have been a contraction in the range of the Imperial Parrot from lower elevations occupied primarily by the Red-necked Parrot (Nichols et al. 1976). On the other hand, even if real, these distributional changes need not reflect competition but could be due to other factors such as, for example, differences in tolerance of human disturbance between the two species. The Imperial Parrot clearly has a lower tolerance of human disturbance. One may speculate that this is because in the past a much higher proportion of encounters with humans were with hunters than for Red-necked Parrots, which would frequently also occur in the vicinity of humans that showed them no harm.

During the course of our fieldwork over the last 12 years, we have no direct evidence that one parrot species interferes with the other. The two species occasionally occur in mixed flocks, and not uncommonly will feed together in the same tree, with no agonistic behaviour between them. Furthermore, a more detailed analysis of the altitudinal distribution of the two species shows that whereas the Imperial Parrot has a narrower altitudinal range, primarily between 1,200 and 3,500 ft (400-1,100 m) as against the Red-necked Parrot's 200-3,500 ft 
$(60-1,100 \mathrm{~m})$, the two species show maximum densities at the same altitudes, $c$. $1,600-1,800 \mathrm{ft}$ ( $500-600 \mathrm{~m}$ ) (Figure 9). Although we cannot yet be sure why both species should be commonest at these altitudes, the forests there are in a climax condition, with a canopy level of $c .90-105 \mathrm{ft}(30-35 \mathrm{~m})$ and tree species such as Dacryodes excelsa, Sloanea spp., Licania ternatensis, Amanoa caribaea, Simarouba amara, and Richeria grandis predominating. All of these trees are known to be

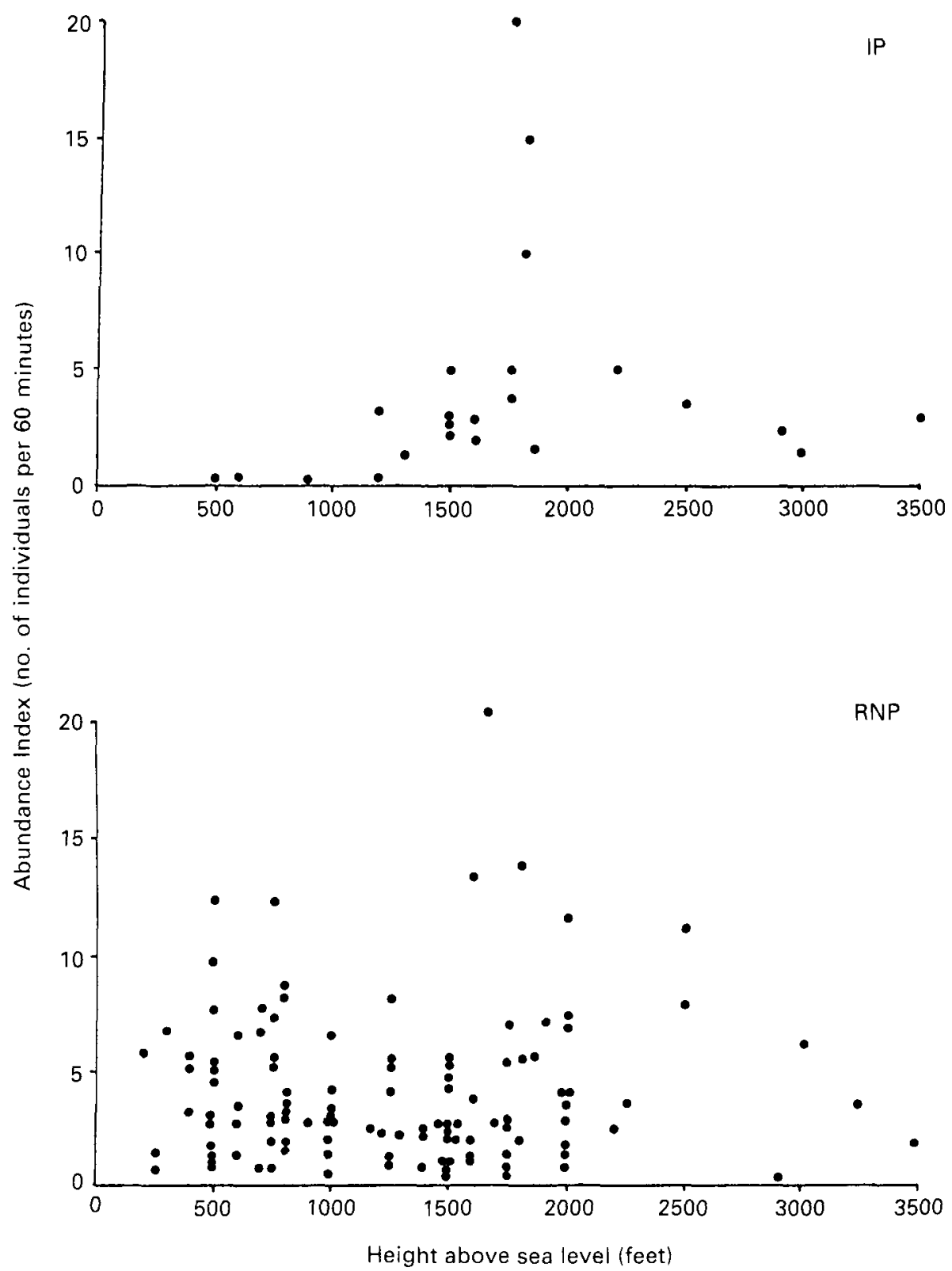

Figure 9. Population density and altitudinal range of Imperial Parrot (IP) and Red-necked Parrot (RNP). 
important food-plants for both parrot species, and the first three are also used particularly as nesting trees (Evans 1988).

If competition between the two species does exist, it may be reflected only when one species becomes much commoner than the other and so excludes it. Thus the changing fortunes of the two species, resulting from the differential impact that habitat loss, hunting and disturbance has upon them, may in turn affect their own interspecific relations. More study of this difficult subject is clearly needed.

\section{Acknowledgements}

The studies I have conducted in Dominica could not have been carried out without the sterling support of members of my teams, and of the staff of the Forestry Division led by Christopher Maximea and Felix Gregoire. To those, I owe a special thanks. The visits have been funded by a wide variety of organisations, and I should like to thank in particular the International Council for Bird Preservation (and notably Michael Rands) who have been faithfully supportive of the project. Thanks also go to the Fauna and Flora Preservation Society, the Royal Society, British Ecological Society, American Federation of Aviculture, Federation of British Zoological Parks and Bird Gardens, and the fundraising efforts of various parrot enthusiasts notably Rosemary Low, Thomas Nichols and Tony Silva. I should also like to thank all those concerned people who at the previous international parrot meeting at Loro Parque, under the direction of Wolfgang Kiessling, donated funds towards the Dominican parrot project. I hope they feel that their efforts have been rewarded.

\section{References}

Butler, P. (1982) Impact of logging on the Dominica Parrot. Unpublished report to CIDA. Roseau, Dominica: Forestry Division.

Butler, P. (1989) The Imperial or Sisserou Parrot and Red-necked Parrot, a new beginning. RARE Center for Tropical Bird Conservation.

Central Statistical Office (1988) The years of growth 1978-1988. Roseau, Dominica: Ministry of Finance.

Clark, A. H. (1905) The West Indian parrots. Auk 22: 337-344.

Evans, P. G. H. (1986) Dominica multiple land use project. Ambio 15: 82-89.

Evans, P. G. H. (1987) Arguments against development of the Dyer Estate for agriculture alone. Memorandum to Director of Forestry and Wildlife, Roseau, Dominica.

Evans, P. G. H. (1988) The conservation status of Imperial and Red-necked Parrots on Dominica. Cambridge, U.K.: International Council for Bird Preservation (Study Report 21).

Evans, P. G. H. (1989) Dominica multiple land use project. Pp.81-88 in Wildlife Management in the Caribbean Islands. Proceedings of the 4 th Meeting of Caribbean Foresters. Rio Pedras, Puerto Rico: Institute of Tropical Forestry.

Evans, P. G. H. and Grieve, A. (1978) Aspects of the biology of the Imperial and Rednecked Parrots. Oxford: unpublished report to the Royal Society.

Forestry Division (1981) Emergency protection for the Amazona parrots of Dominica following the passage of Hurricane David. Roseau, Dominica: unpublished report to World Wildlife Fund.

Gregoire, F. W. (1981) The dilemma of the Amazona imperialis and Amazona arausiaca parrots in Dominica following Hurricane David in 1979. Pp.161-167 in R. F. Pasquier, ed. Conservation of New World parrots. Washington, D.C.: Smithsonian Institution Press for the International Council for Bird Preservation (Techn. Publ. 1). 
Howes, P. G. (1929) The mountains of Dominica. Natural History 29: 595-610.

International Council for Bird Preservation (1990) The development of Morne Diablotin National Park and Nature Centre in the Commonwealth of Dominica 1990 to 1993. Roseau, Dominica: Forestry \& Wildlife Division; Cambridge, U.K.: International Council for Bird Preservation.

Lawrence, G. N. (1878) Catalogue of the birds of Dominica from collections made for the Smithsonian Institution by Frederick $A$. Ober, together with his notes and observations. Proc. U.S. Natn. Mus. 31: 48-69.

Lawrence, G. N. (1880) Description of a new species of parrot of the genus Chrysotis, from the island of Dominica. Proc. U.S. Natn. Mus. 3: 254-257.

Lugo, A. E., Applefield, M., Pool, D. J. and McDonald, R. B. (1983) The impact of Hurricane David on the forests of Dominica. Can. J. Forestry Res. 13: 201-211.

Maximea, C. C. (1983) Proposed water-catchment and wilderness preserve: Morne Plaisance, Dyer, Syndicate, Milton, Jude Estates area. Memoranda (August 9 and August 16, 1983) to Permanent Secretary/Agriculture. Roseau, Dominica: Forestry Division.

Nichols, H. A. J., Nichols, C. A., van Vliet, G. B. and Gray, G. S. (1976) Endangered amazons of Dominica: the Imperial and Arausiaca Parrots. Unpublished report to ICBP, Washington, U.S.A.

Nichols, T. D. (1981) Observation on Amazona imperialis during the second nesting season after Hurricane David. Unpublished report to ICBP, Cambridge.

Nichols, T. D. (1986) Amazona imperialis and a story of an Albatross. Amazona Newsletter Suppl. No. 1.

Ober, F. A. (1878) Ornithological exploration of the Caribee Islands. Ann. Rep. Smithson. Inst. for year 1878: 446-451.

Porter, S. (1929) In search of the Imperial Parrot. Avic. Mag. (4) 7: 240-246, 267-275.

Snyder, N. F. R. and Snyder, H. A. (1979) An assessment of the status of parrots of Dominica following Hurricane David. Unpublished report to ICBP.

Snyder, N. F. R. and Taapken, J. D. (1978) Puerto Rican Parrots and nest predation by Pearly-eyed Thrashers. Pp.113-120 in S. A. Temple, ed. Endangered birds - management techniques for preserving threatened species. Madison: University of Wisconsin Press.

Verrill, G. E. (1892) Fauna of the Island of Dominica: order Psittaci. Trans. Connect. Acad. Arts and Sciences 8: 327-329.

Verrill, G. E. (1905) Addition to the avifauna of Dominica. Notes of species hitherto unrecorded with descriptions of three new species and a list of all birds now known to occur on the island. Barbados: privately published.

Wiley, J. (1981) The Puerto Rican Amazon (Amazona vittata): its decline and the program for its conservation. Pp.133-159 in R. F. Pasquier, ed. Conservation of New World parrots. Washington, D.C.: Smithsonian Institution Press for International Council for Bird Preservation (Techn. Publ. 1).

Zamore, M. (1982) Effect of rotary (logging) operations at Morne Plaisance on parrot populations. Memorandum (30 June 1982) to Director of Forestry, Forestry Division, Roseau, Dominica.

PETER G. H. EVANS

Edward Grey Institute of Field Ornithology, Department of Zoology, University of Oxford, South Parks Road, Oxford OX1 3 PS, U.K. 